Life Science 10 (2) (2021)

Life Science

http://journal.unnes.ac.id/sju/index.php/LifeSci

\title{
Pengaruh Zat Pengatur Tumbuh 2,4-D dan Kinetin terhadap Pertumbuhan dan Morfologi Sel Gembili (Dioscorea esculenta)
}

\author{
Anisa Dewi Sri Puspitasari ${ }^{1)}$, Noor Aini Habibah ${ }^{\bowtie 1)}$ \\ ${ }^{1)}$ Laboratorium Kultur Jaringan Tumbuhan, Fakultas Matematika dan Ilmu Pengetahuan Alam, Universitas Negeri \\ Semarang
}

\begin{tabular}{l}
\hline Info Artikel \\
\hline Diterima: 1 September \\
2021 \\
Disetujui: 30 September \\
2021 \\
Dipublikasikan: 30 \\
November 2021 \\
\hline Keywords: \\
2,4-dichlorophenoxyacetic \\
acid, kinetin, Dioscorea \\
esculenta, culture cell. \\
2,4-dichlorophenoxyacetic \\
acid, kinetin, Dioscorea \\
esculenta, kultur sel. \\
\end{tabular}

\begin{abstract}
Gembili (Dioscorea esculenta) bioactive compounds that can be used for treatment. Cell culture is a method that can be used to produce bioactive compounds from plant. The success of cell culture techniques is influenced by the type and concentration of plant growth (PGR). This study aims to analyze the effect of 2,4-D and kinetin on the growth and morphology of gembili cells. Murashige \& Skoog (MS) medium with the addition of 2,4-D and kinetin (1 ppm 2,4-D + 1 ppm kinetin; 1 ppm 2,4-D + 0,5 ppm kinetin; 0,5 ppm 2,4-D + 1 ppm kinetin; 0,5 ppm 2,4-D +0,5 ppm kinetin; and 0 ppm 2,4-D + 0 ppm kinetin) were used for gembili cell growth. The observed parameters are fresh weight and morphology of cells. The results showed that the combination of 1 ppm 2,4-D + 1 ppm kinetin produces the highest fresh weight $(2,1782 \mathrm{~g})$. The resulting cells are predominantly globular, but there are some that differentiate into elongated ones. Cell color in all treatments was variated from light brown to darker brown. The findings may provide preliminary information using cell suspension cultures in the production of secondary metabolites from Dioscorea esculenta.
\end{abstract}

\begin{abstract}
Abstrak
Gembili (Dioscorea esculenta) menghasilkan senyawa bioaktif yang dapat dimanfaatkan untuk pengobatan. Kultur sel merupakan metode yang dapat digunakan untuk produksi senyawa bioaktif yang terkandung dalam tumbuhan. Keberhasilan dari teknik kultur sel di antaranya dipengaruhi oleh jenis dan konsentrasi zat pengatur tumbuh (ZPT). Penelitian ini bertujuan untuk menganalisis pengaruh ZPT 2,4-D dan kinetin terhadap pertumbuhan dan morfologi sel gembili. Variabel bebas yang digunakan pada penelitian ini yaitu kombinasi antara ZPT 2,4-D dan kinetin (1 ppm 2,4-D + 1 ppm kinetin; 1 ppm 2,4-D + 0,5 ppm kinetin; 0,5 ppm 2,4-D + 1 ppm kinetin; 0,5 ppm 2,4-D + 0,5 ppm kinetin; dan 0 ppm 2,4-D + 0 ppm kinetin). Tipe kultur yang digunakan adalah kultur suspensi sel menggunakan media MS dengan penggojogan. Variabel terikat pada penelitian ini yaitu berat basah dan morfologi sel. Hasil penelitian menunjukkan bahwa kombinasi antara ZPT 1 ppm 2,4-D + 1 ppm kinetin menghasilkan berat basah yang paling tinggi yaitu sebesar 2,1782 gram. Sel yang dihasilkan dominan berbentuk globular, namun ada beberapa yang berdiferensiasi menjadi memanjang, sedangkan warna sel bervariasi dari cokelat muda hingga cokelat tua. Temuan dapat menjadi informasi awal menggunakan kultur suspensi sel dalam produksi senyawa metabolit sekunder dari gembili.
\end{abstract}

(C) 2021 Universitas Negeri Semarang

$\square$ Alamat korespondensi: p-ISSN 2252-6277

Gedung D11 Lt.1 J1 Raya Sekaran Gunugpati, Semarang

E-mail: nooraini@mail.unnes.ac.id

e-ISSN 2528-5009 


\section{PENDAHULUAN}

Gembili (Dioscorea esculenta) merupakan tumbuhan dari jenis umbi-umbian, memiliki kandungan senyawa bioaktif yang dapat dimanfaatkan di bidang kesehatan. Kandungan senyawa bioaktif yang terdapat pada gembili yaitu inulin berupa oligosakarida (Khasanah et al., 2019), dioscorin, dan diosgenin. Senyawa bioaktif dioscorin memiliki aktivitas imuno modulator (Liu et al., 2009), antioksidan (Nagai \& Nagashima, 2006,) serta dapat dimanfaatkan sebagai penghambat enzim angiotensin sehingga hipertensi dapat terkontrol (Hsu et al., 2002). Senyawa bioaktif diosgenin berperan dalam sintesis beberapa obat steroid dalam bidang farmasi dan sebagai agen kemopreventif kanker (Raju \& Mehta, 2008). Namun sayangnya di Indonesia pemanfaatan gembili belum optimal. Gembili seringkali hanya digunakan sebagai bahan pangan padahal di dalam umbi gembili terkandung senyawa bioaktif yang memiliki berbagai manfaat.

Kultur sel merupakan metode yang dapat digunakan untuk menghasilkan senyawa bioaktif. Kelebihan dari teknik ini dibandingkan dengan teknik lain yaitu eksplan yang digunakan berupa sel yang masih aktif membelah sehingga proses isolasinya berjalan lebih mudah. Selain itu teknik ini tidak membutuhkan lahan yang luas, produksi senyawa bioaktif dapat dikontrol, dan tidak bergantung pada perubahan iklim (Collin \& Edward, 1998). Dalam kultur sel dibutuhkan lingkungan yang steril untuk menghindari kontaminasi yang disebabkan oleh bakteri, jamur, dan virus. Selain itu juga membutuhkan media kultur yang terdiri dari air, vitamin, sukrosa, garam anorganik, dan hormon tanaman (Moscatiello, et al., 2013).

Zat pengatur tumbuh (ZPT) dalam kultur sel berperan penting untuk memacu pertumbuhan dan perkembangan sel. Tanpa adanya ZPT maka pertumbuhan sel akan terhambat. Menurut Gamborg \& Phillips (1995), pemilihan jenis dan konsentrasi ZPT menentukan tingkat keberhasilan eksplan untuk tumbuh. Tan et al. (2010) menyatakan, konsentrasi ZPT terbaik untuk merangsang pertumbuhan sel Centella asiatica serta untuk produksi senyawa metabolit sekunder flavonoid yaitu $2 \mathrm{mg}$ /L 2,4-D dan 1 mg/L kinetin. Habibah (2009) melaporkan, medium yang paling optimal untuk pertumbuhan sel sambiloto adalah medium dengan penambahan ZPT 0,5 ppm kinetin dan 5 ppm 2,4-D. Menurut Zakiah et al. (2003), konsentrasi ZPT terbaik untuk pertumbuhan kultur suspensi sel Azadirachta indica yaitu 0,1 $\mu \mathrm{M}$ 2,4-D dan 1,0 $\mu \mathrm{M}$ BAP. Khandy et al. (2016) menggunakan $1 \mathrm{mg} / \mathrm{L} 2,4-\mathrm{D}$ and 0,1 mg/L kinetin untuk menghasilkan senyawa protodiosin dan isomer-isomer deltosida pada suspensi sel Dioscorea deltoidea. Sementara itu, Titova et al. (2021) juga menggunakan $1 \mathrm{mg} / \mathrm{L}$ 2,4-D and 0,1 mg/L kinetin untuk menghasilkan urostanol glikosida dari suspensi sel Dioscorea deltoidei. 


\section{METODE}

Sel yang digunakan berasal dari kalus umbi gembili umur 3 bulan yang ditanam pada media MS padat dengan kondisi pencahayan gelap. Variabel bebas pada penelitian ini yaitu kombinasi antara ZPT 2,4-D dengan kinetin, yaitu 1 ppm 2,4-D + 1 ppm kinetin; 1 ppm 2,4-D + 0,5 ppm kinetin; 0,5 ppm 2,4-D + 1 ppm kinetin; 0,5 ppm 2,4-D + 0,5 ppm kinetin; dan 0 ppm 2,4-D + 0 ppm kinetin. Variabel terikat pada penelitian ini meliputi berat basah dan morfologi sel. Variabel kontrol terdiri dari $\mathrm{pH}$ medium, suhu ruang tanam, suhu ruang inkubasi $\left(20^{\circ} \mathrm{C}\right)$, dan kecepatan shaker $(120 \mathrm{rpm})$.

\section{Kultur Sel.}

Media yang digunakan adalah media MS (Murashige and Skoog) cair dengan penambahan ZPT 2,4-D dan kinetin, yaitu 1 ppm 2,4-D + 1 ppm kinetin; 1 ppm 2,4-D + 0,5 ppm kinetin; 0,5 ppm 2,4-D + 1 ppm kinetin; 0,5 ppm 2,4-D + 0,5 ppm kinetin; dan 0 ppm 2,4-D + 0 ppm kinetin. Kalus dipotong sebesar 1 gram kemudian dimasukkan ke dalam media cair, setelah itu ditutup menggunakan alumunium foil dan diikat menggunakan karet. Bagian atas erlenmeyer dibungkus menggunakan plastik wrap. Setelah itu erlenmeyer diletakkan di inkubator shaker selama 30 hari dengan kecepatan $120 \mathrm{rpm}$. Perhitungan berat basah dan pengamatan morfologi sel dilakukan setelah sel berumur 30 hari. Untuk penentuan warna sel dilakukan dengan melihat warna sel secara langsung tanpa bantuan mikroskop binokuler, kemudian warna sel tersebut dibandingkan dengan bagan warna standar yang dilengkapi dengan skor berbeda.

\section{Analisis Data dan Uji Statistik.}

Perhitungan berat basah sel dilakukan dengan menggunakan Anova satu arah dengan taraf kesalahan $\alpha=0,05$. Jika hasil uji Anova berbeda nyata, maka dilakukan uji lanjut LSD (Least Significant Difference). Data dianalisis menggunakan perangkat SPSS versi 20.0, sedangkan morfologi sel dianalisis secara deskriptif.

\section{HASIL DAN PEMBAHASAN}

Kalus yang digunakan pada penelitian ini yaitu kalus remah yang berwarna putih kekuningan. Menurut Habibah (2009), kalus remah merupakan kalus yang ideal untuk digunakan dalam kultur sel karena terdapat ruang antar sel yang lebar. Ruang antar sel tersebut memudahkan terpisahnya sel satu dengan sel lain pada saat pengocokan di dalam inkubator shaker. Data berat basah dan morfologi sel gembili disajikan pada Tabel 1, 2, dan 3 . 
Tabel 1. Berat basah sel gembili pada Medium MS dengan penambahan ZPT 2,4-D dan kinetin

\begin{tabular}{ccc}
\hline \multicolumn{2}{c}{ ZPT $(\mathbf{p p m})$} & \multirow{2}{*}{ Rerata Berat Basah $(\mathbf{g})$} \\
\cline { 1 - 2 } 2,4-D & Kinetin & \\
\hline 0 & 0 & $0,9654^{\mathrm{b}}$ \\
1 & 1 & $2,1782^{\mathrm{a}}$ \\
1 & 0,5 & $1,4566^{\mathrm{ab}}$ \\
0,5 & 1 & $1,8985^{\mathrm{ab}}$ \\
0,5 & 0,5 & $1,6303^{\mathrm{ab}}$ \\
\hline
\end{tabular}

Keterangan: Huruf yang sama di belakang angka menunjukkan tidak adanya perbedaan secara nyata, sedangkan huruf yang berbeda menunjukkan adanya perbedaan nyata.

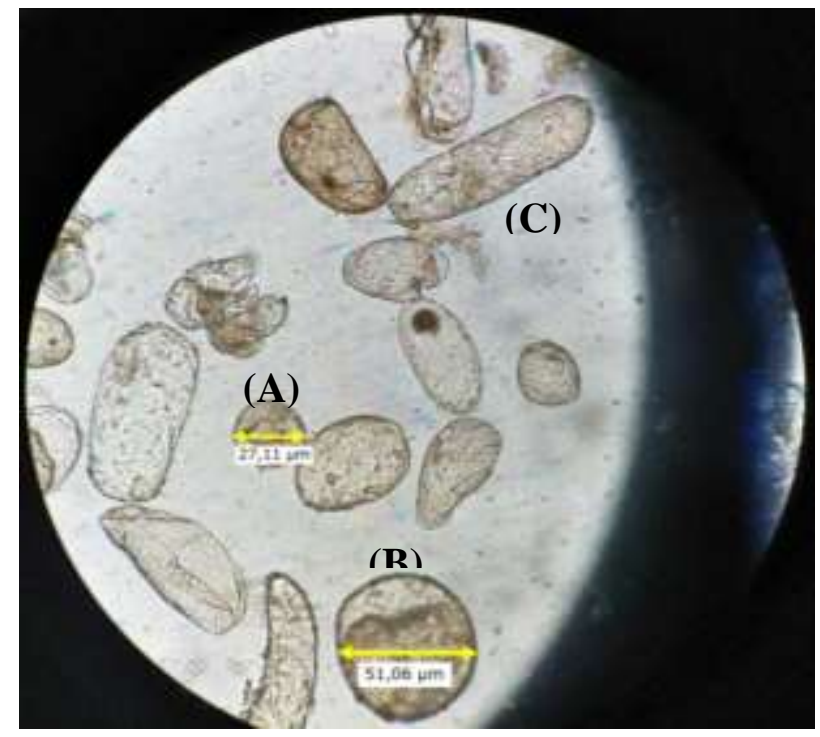

Gambar 1. Sel D. esculenta (A) Sel Globular kecil ( $\leq 50 \mu \mathrm{m})$; (B) Sel Globular besar ( $>50 \mu \mathrm{m})$; (C) Sel berbentuk memanjang.
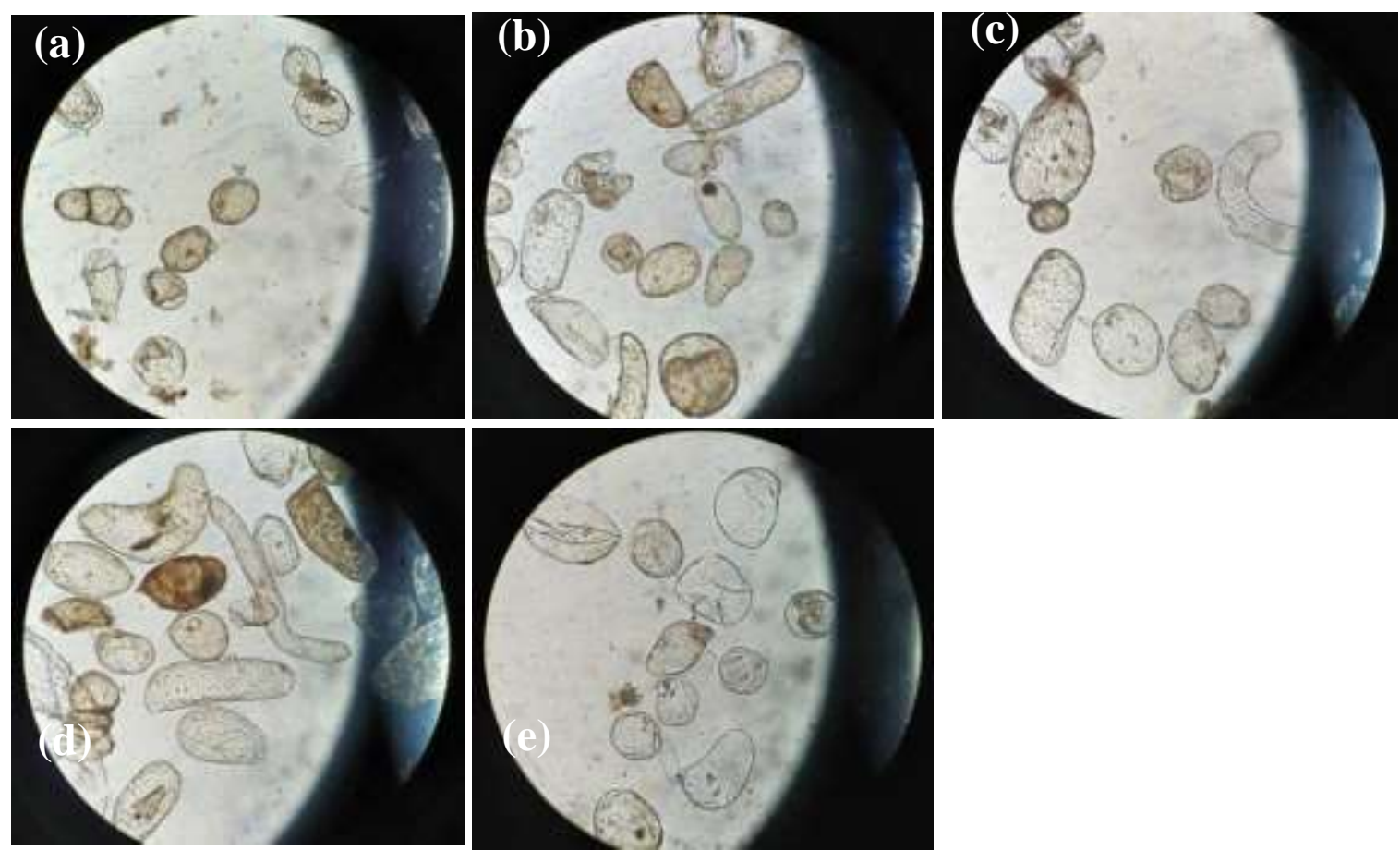
Gambar 2. Sel gembili umur 30 hari (a) 0 ppm 2,4-D + 0 ppm kinetin; (b) 1 ppm 2,4-D + 1 ppm kinetin; (c) 1 ppm 2,4-D + 0,5 ppm kinetin; (d) 0,5 ppm 2,4-D + 1 ppm kinetin; (e) 0,5 ppm 2,4-D + 0,5 ppm kinetin.

Tabel. 2. Hasil pengamatan visual warna sel gembili umur 30 hari

\begin{tabular}{llcc}
\hline \multicolumn{2}{c}{ ZPT } & Foto Sel & Keterangan \\
\hline 2,4-D & Kinetin & & \\
\hline $0 \mathrm{ppm}$ & $0 \mathrm{ppm}$ & & \\
\hline
\end{tabular}

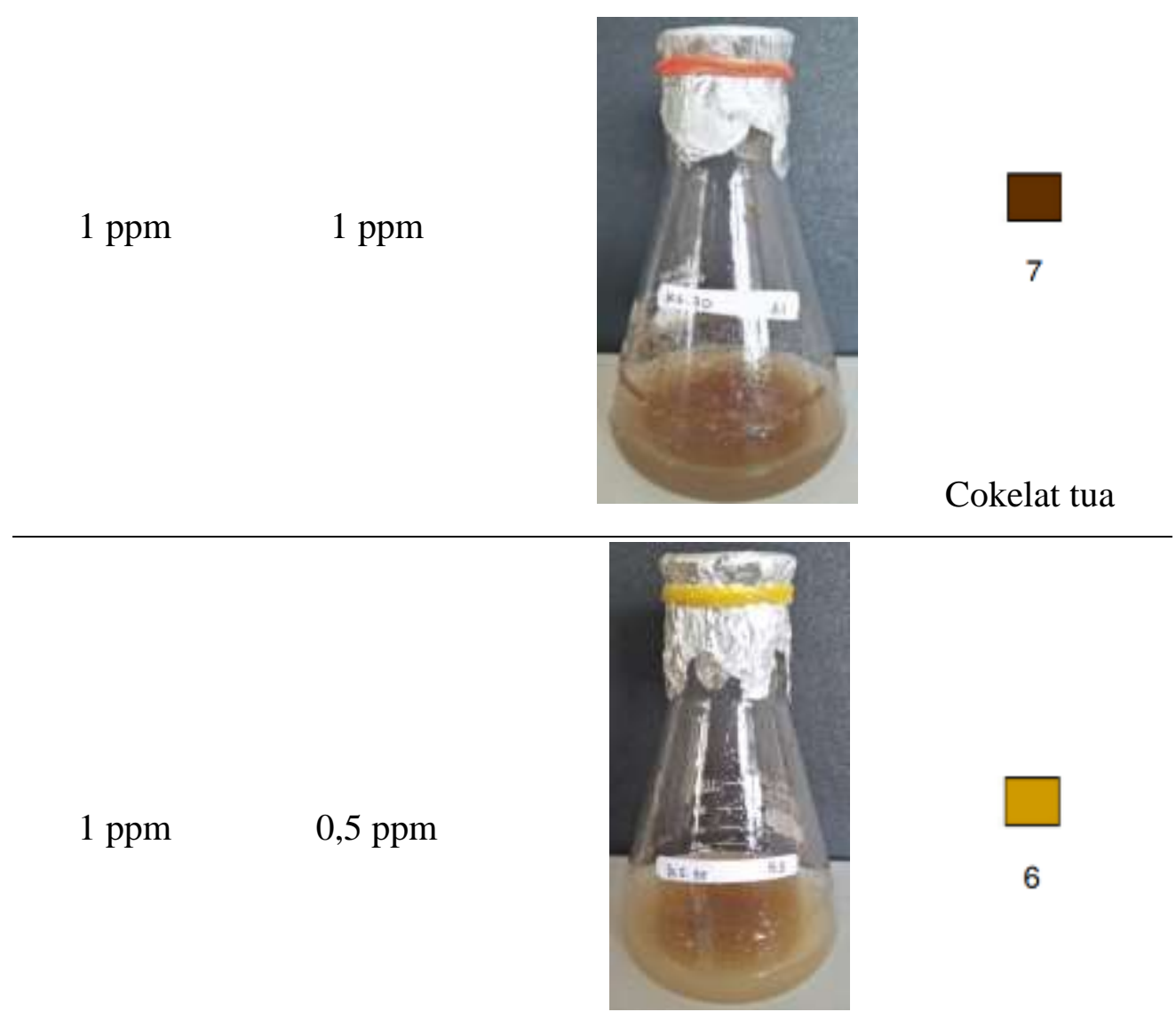

Cokelat muda 


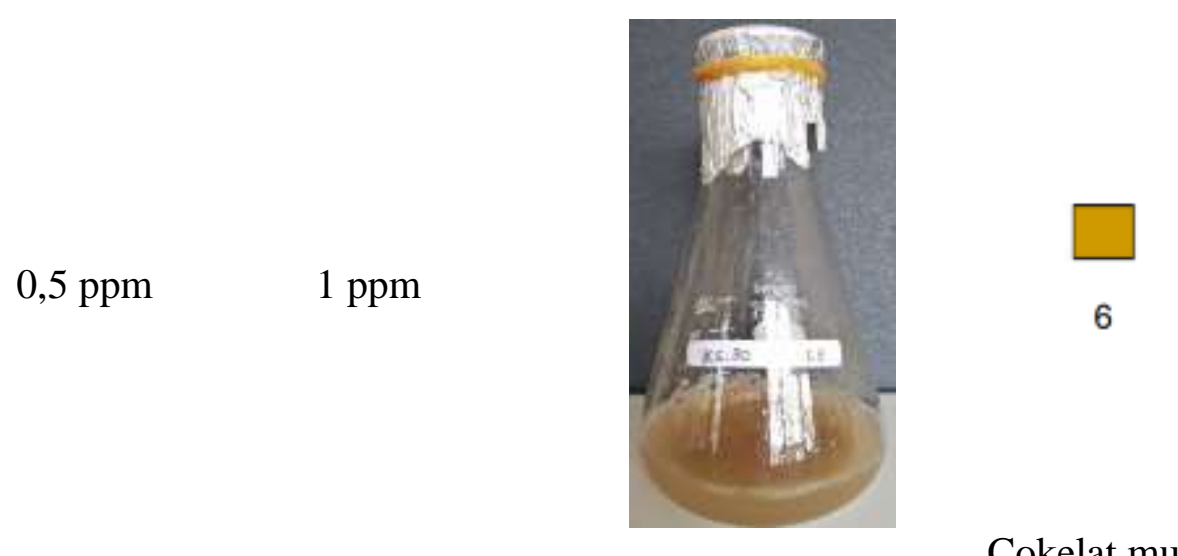

Cokelat muda

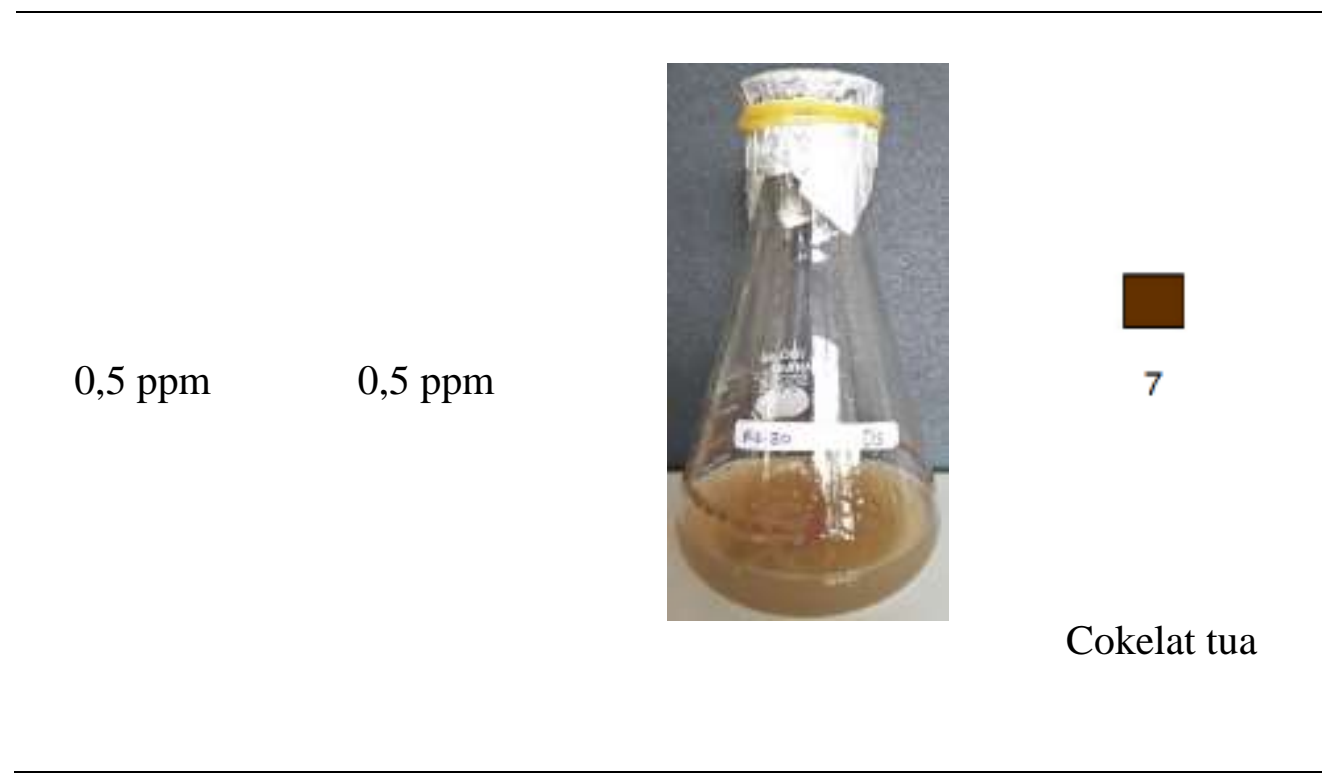

Tabel 3. Persentase bentuk sel gembili

\begin{tabular}{ccccc}
\hline \multicolumn{2}{c}{ ZPT (ppm) } & \multicolumn{3}{c}{ Morfologi Sel (\%) } \\
\hline 2,4-D & Kinetin & Globular kecil & Globular besar & $\begin{array}{c}\text { Sel } \\
(\leq 50 \mu \mathrm{m})\end{array}$ \\
\hline 0 & 0 & 55 & 25 & 20 \\
1 & 1 & 40 & 43 & 17 \\
1 & 0,5 & 45 & 32 & 23 \\
0,5 & 1 & 42 & 28 & 30 \\
0,5 & 0,5 & 48 & 40 & 12 \\
\hline
\end{tabular}

Parameter yang digunakan untuk menentukan pertumbuhan sel yaitu berat basah sel. Berdasarkan Tabel 1, terlihat bahwa konsentrasi ZPT yang paling tinggi untuk pertumbuhan sel gembili yaitu 1 ppm 2,4-D + 1 ppm kinetin dengan rerata berat basah sebesar 2,1782 gram. Pada perlakuan tanpa 
ZPT, berat basah yang dihasilkan lebih rendah dibandingkan dengan perlakuan lain, yaitu 0,9654 gram. Hasil ini menunjukkan bahwa penambahan ZPT 2,4-D dan kinetin berpengaruh terhadap pertumbuhan sel gembili. Hasil penelitian ini juga sejalan laporan Khandy et al. (2016) dan Titova et al. (2021) yang menggunakan menggunakan $1 \mathrm{mg} / \mathrm{L}$ 2,4-D untuk masing-masing untuk menghasilkan protodiosin serta isomer-isomer deltosida dan urostanol glikosida dari suspensi sel Dioscorea deltoidei, meskipun dengan konsentrasi kinetin lebih kecil, yaitu and $0,1 \mathrm{mg} / \mathrm{L}$.

Hasil penelitian ini juga sejalan dengan pernyataan Habibah et al. (2009) bahwa laju pertumbuhan kalus dari eksplan petiole muda Elaeocarpus grandiflorus dipengaruhi oleh jenis dan konsentrasi ZPT. Selain itu menurut Sulichantini (2016), kombinasi ZPT terbaik untuk pertumbuhan tunas bawang putih diperoleh pada perlakuan $1 \mathrm{mg} / \mathrm{l} \mathrm{NAA}+3 \mathrm{mg} / \mathrm{l}$ kinetin. Pada perlakuan tanpa ZPT, eksplan memerlukan waktu yang lebih lama untuk tumbuh. Siregar (2008) menyampaikan, ZPT terbaik untuk pertumbuhan sel Eurycoma longifolia yaitu 2,32 $\mu \mathrm{M}$ kinetin $+2,69 \mu \mathrm{M}$ NAA $+1,13 \mu \mathrm{M}$ 2,4-D dengan peningkatan berat basah dari 6,255 g menjadi 6,428 g. Penambahan ZPT 2,4-D ke dalam media mampu meningkatkan pembelahan sel sedangkan penambahan kinetin dapat mengatur pembelahan sel dan morfogenesis (Gunawan, 1992).

Morfologi sel yang diamati terdiri dari dua jenis yaitu bentuk dan warna sel. Bentuk sel gembili disajikan pada Tabel 3. Pada perlakuan 0 ppm 2,4-D + 0 ppm kinetin terlihat bahwa tingkat pertumbuhan sel lebih rendah dibandingkan dengan perlakuan lain. Pada perlakuan ini sel globular kecil yang dihasilkan yaitu 55\%, sel yang tumbuh menjadi sel globular besar yaitu 25\% dan $20 \%$ sisanya terdiferensiasi memanjang. Pada perlakuan 1 ppm 2,4-D + 1 ppm kinetin menunjukkan tingkat pertumbuhan sel tertinggi dibandingkan dengan perlakuan lain. Pada perlakuan ini terdapat $40 \%$ sel berbentuk globular kecil, sel yang tumbuh menjadi sel globular besar sebanyak $43 \%$ dan 17\% terdiferensiasi menjadi sel memanjang. Hal ini menunjukkan bahwa penambahan ZPT berpengaruh terhadap morfologi sel. Pada penelitian ini seluruh perlakuan didominasi oleh sel globular, sedangkan sel yang berdiferensiasi memanjang hanya ada dalam jumlah kecil.

Tingginya tingkat pembelahan sel menyebabkan pembentukan sel-sel globular kecil pada media meningkat. Sel globular kecil tersebut nantinya akan tumbuh menjadi sel globular berukuran besar dan selanjutnya akan terdiferensiasi menjadi sel memanjang. Hal ini sejalan dengan penelitian Habibah et al. (2017) yang melaporkan bahwa pada semua perlakuan kultur suspensi sel Stelechocarpus burahol didominasi oleh sel berbentuk globular yang berukuran $<50 \mu \mathrm{m}$. Selain itu Sparapano \& Bruno (2004) melaporkan bahwa sel globular mendominasi kultur sel Cupressus arizonica hingga akhir masa pertumbuhannya. 
Warna sel yang dihasilkan pada perlakuan 1 ppm 2,4-D + 1 ppm kinetin yaitu cokelat tua. Warna sel pada perlakuan ini lebih tua dibandingkan dengan perlakuan lain. Semakin tinggi konsentrasi ZPT yang digunakan maka warna sel yang dihasilkan semakin tua. Warna cokelat tersebut diduga disebabkan adanya kandungan senyawa flavonoid yang terkandung di dalam sel. Warna cokelat merupakan penyebab dari adanya kandungan senyawa flavonoid di dalam sel yang teroksidasi oleh oksigen. Lim (2016) melaporkan bahwa gembili memiliki kandungan senyawa metabolit sekunder seperti flavonoid, saponin, dan inulin. Selain itu Siswati et al. (2019) juga melaporkan bahwa kandungan senyawa bioaktif yang terdapat di dalam gembili antara lain flavonoid, steroid, dan terpenoid dengan jumlah yang bervariasi.

\section{KESIMPULAN}

Pertumbuhan sel gembili (D. esculenta) dipengaruhi oleh jenis dan konsentrasi zat pengatur tumbuh. Penambahan ZPT dengan konsentrasi kurang dari 1 ppm menghasilkan pertumbuhan yang rendah. Pada perlakuan 1 ppm 2,4-D + 1 ppm kinetin menghasilkan pertumbuhan sel gembili yang tertinggi yaitu sebesar 2,1782 gram. Selain itu pada perlakuan ini sel yang tumbuh dari sel globular kecil menjadi sel globular besar memiliki persentase yang lebih tinggi dibandingkan dengan perlakuan lain. Pada perlakuan ini warna sel yang dihasilkan yaitu cokelat tua. Sel berbentuk globular mendominasi kultur sel pada semua perlakuan dengan warna sel yang bervariasi dari cokelat muda sampai cokelat tua.

\section{DAFTAR PUSTAKA}

Collin, H.A. \& Edward, S. (1998). Plant Cell Culture. UK: BIOS Scientific Publisher.

Gamborg, O. L., \& Phillips, G. C. (1995). Media preparation and handling. Plant Cell, Tissue and Organ Culture. Berlin, Heidelberg: Spinger-Verlag.

Gunawan, L.W. (1992). Teknik Kultur Jaringan Tumbuhan. Jakarta: Departemen Pendidikan dan Kebudayaan, Direktorat Jenderal Pendidikan Tinggi, Pusat Antar Universitas Bioteknologi IPB.

Habibah, N.A. (2009). Efektivitas penambahan elisitor asam jasmonik dalam peningkatan sintesis senyawa bioaktif andrografolid pada kultur suspensi sel sambiloto (Effectiveness of jasmonic acid elicitor addition for andrographolide synthesis induction of sambiloto culture). Biosaintifika: Journal of Biology \& Biology Education, 1(1). 11-18.

Habibah, N.A., Moeljopawiro, S., Dewi, K., \& Indrianto, A. (2017). Flavonoid production, growth and differentiation of Stelechocarpus burahol (B1.) Hook. F. and Th. Cell Suspension Culture. Pakistan Journal of Biological Sciences: PJBS, 20(4), 197-203. 
Habibah, N.A., Widiatningrum, T., Anggraito, Y.U., Rahayu, E.S., Mukhtar, K., Wijayanti, N., \& Mustafa, F. (2019). Growth of Elaeocarpus grandiflorus callus cultures in MS medium with various concentrations of growth regulators. In Journal of Physics: Conference Series, $1321(3), 032037$.

Hsu, F.L., Lin, Y.H., Lee, M.H., Lin, C.L. \& Hou, W.C. (2002). Both dioscorin, the tuber storage protein of yam (Dioscorea alata cv. Tainong No.1), and its peptic hydrolysates exhibited angiotensin-converting enzyme inhibitory activities. Journal of Agricultural and Food Chemistry, 50(21), 6109-6113.

Khandy, M.T., Titova, M.V., Konstantinova, S.V., Kochkin, D.V., Ivanov, I.M., Nosov, A.M. (2016). Formation of protodioscin and deltoside isomers in suspension cultures of Nepal yam (Dioscorea deltoidea Wall.) cells. Applied of Biochemical and Microbiology, 52, 657-662.

Khasanah, Y., Nurhayati, R., Btari, S., \& Ratnaningrum, E. (2019). Isolation oligosaccharides from gembili (Dioscorea esculenta Lour. Burkill) as prebiotics. IOP Conference Series: Materials Science and Engineering, 633(1), 012006.

Lim, T. K. (2016). Edible Medicinal and Non-Medicinal Plants, New York: Springer.

Liu, Y.W., Liu, J.U.C., Huang, C.Y., Wang, C.K., Shang, H.F. \& Hou, W.C. (2009). Effects of oral administration of yam tuber storage protein, dioscorin, to BALB/c mice for 21 days on immune responses. Journal of Agricultural and Food Chemistry, 57(19), 9274-9279.

Moscatiello, R., Baldan, B., \& Navazio, L. (2013). Plant Cell Suspension Cultures. Method of Molecular Biology, 953: 77-93. DOI: 10.1007/978-1-62703-152-3_5.

Nagai, T., \& Nagashima, T. (2006). Functional properties of dioscorin, a soluble viscous protein from Japanese yam (Dioscorea opposita Thunb.) tuber mucilage tororo. Zeitschrift Fur Naturforschung-Section C Journal of Biosciences, 61(11-12), 792-798.

Raju, J., \& Mehta, R. (2008). Cancer chemopreventive and therapeutic effects of diosgenin, a food saponin. Nutrition and cancer, 61(1), 27-35.

Siregar, L.A.M. (2008). Pengaruh sitokinin eksogen dan sukrosa terhadap produksi biomassa dan alkaloid canthinone di dalam kultur suspensi sel pasak bumi (Eurycoma longifolia Jack.). Jurnal Natur Indonesia, 12(2), 143-151.

Siswati, O.D., Bintoro, V.P., \& Nurwantoro, N. (2019). Karakteristik es krim ubi jalar ungu (Ipomoea batatas var ayamurasaki) dengan penambahan tepung umbi gembili (Dioscorea esculenta L.) sebagai bahan penstabil. Jurnal Teknologi Pangan, 3(1): 121- 126.

Sparapano, L., \& Bruno, G. (2004). Cupressus callus and cell suspension cultures: effect of seiridins on their growth and sensitivity. In Vitro Cellular \& Developmental Biology-Plant, 40(6), 617-625.

Sulichantini, E.D. (2016). Pengaruh konsentrasi zat pengatur tumbuh terhadap regenerasi bawang putih (Allium sativum L) secara kultur jaringan. Agrifor: Jurnal Ilmu Pertanian dan Kehutanan, 15(1), 29-36.

Titova, M.V., Popova, E.V., Konstantinova, S.V., Kochkin, D.V., Ivanov, I.M., Klyushin, A.G., Titova, E.G., Nebera, E.A., Vasilevskaya, E.R., Tolmacheva, G.S., et al. (2021). Suspension cell culture of Dioscorea deltoidea, A renewable source of biomass and furostanol glycosides for food and pharmaceutical industry. Agronomy, 11, 394. https://doi.org/10.3390/ agronomy 11020394

Tan, S.H, Radzali, M., Arbakariya, A., \& Mahmood, M. (2010). Effect of plant growth regulators on callus, cell suspension and cell line selection for flavonoid production from pegaga (Centella asiatica L. Urban). American Journal of Biochemistry and Biotechnology, 6(4), 284-299. 
Zakiah, Z., Marwani, E., \& Siregar, A.H. (2003). Peningkatan produksi azadirahtin dalam kultur suspensi sel Azadirachta indica A. Juss melalui penambahan skualen. Jurnal Matematika dan Sains, 8(4), 141-146. 